\title{
OECD Regional Development Working Papers 2014/11
}

\section{Breathing the Same Air?}

Measuring Air Pollution in Cities and Regions

Monica Brezzi,

\section{Daniel Sanchez-Serra}




\section{OECD REGIONAL DEVELOPMENT WORKING PAPERS}

This series is designed to make available to a wider readership selected studies on regional development issues prepared for use within the OECD. Authorship is usually collective, but principal authors are named. The papers are generally available only in their original language English or French with a summary in the other if available.

OECD Working Papers should not be reported as representing the official views of the OECD or of its member countries. The opinions expressed and arguments employed are those of the author(s).

The statistical data for Israel are supplied by and under the responsibility of the relevant Israeli authorities. The use of such data by the OECD is without prejudice to the status of the Golan Heights, East Jerusalem and Israeli settlements in the West Bank under the terms of international law.

Working Papers describe preliminary results or research in progress by the author(s) and are published to stimulate discussion on a broad range of issues on which the OECD works. Comments on Working Papers are welcomed, and may be sent to either gov.contact@oecd.org or the Public Governance and Territorial Development Directorate, OECD, 2 rue André-Pascal, 75775 Paris Cedex 16, France.

Authorised for publication by Rolf Alter, Director, Public Governance and Territorial Development Directorate, OECD.

OECD Regional Development Working Papers are published on http://www.oecd.org/gov/regional/workingpapers

Applications for permission to reproduce or translate all or part of this material should be made to: OECD Publishing, rights@oecd.org or by fax 33145249930.

(C) OECD 2014 
BREATHING THE SAME AIR? MEASURING AIR POLLUTION IN CITIES AND REGIONS

\author{
Monica Brezzi and Daniel Sanchez-Serra ${ }^{1}$
}

OECD, Regional Development Policy Division

\begin{abstract}
This paper presents a new set of estimates of exposure to air pollution (fine particulate matter PM2.5) at the city, regional and national levels for the 34 OECD countries, and at the regional and national levels for Brazil, China, India, Russia and South Africa. The estimates are developed by the computation of satellite-based observations. They have the advantage of providing consistent values of the magnitude and spatial distribution of air pollution to be compared across and within countries and over time. The paper also explores the association between shape of cities (population density, share of built-up area, extension of the hinterlands, etc.) and air pollution. The estimates of air pollution at (TL2) regional level have been used in the newly released OECD Regional Well-Being Database as a measure of the environmental dimension.
\end{abstract}

JEL classification: Q53, Q56.

Keywords: Air pollution, sub-national disparities, health, urban form.

1. The authors would like to thank Aaron van Donkelaar for providing the satellite-based PM2.5 estimates. Valuable comments to previous version of the paper were provided by Aaron van Donkelaar, Randall Martin, Paolo Veneri, Eric Gonnard, Marc-Antoine Fayet, Lewis Dijkstra, Laura Dupont-Courtade and Walid Oueslati. 
TABLE OF CONTENTS

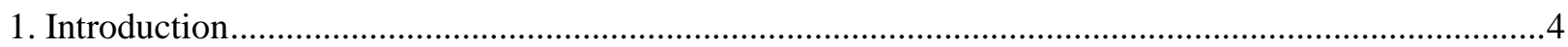

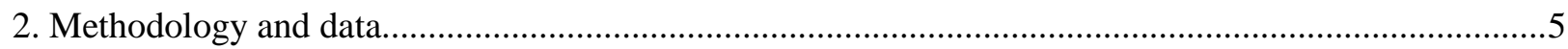

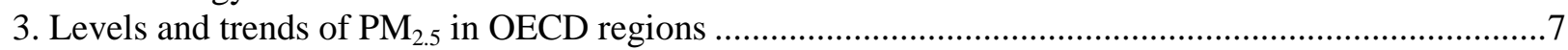

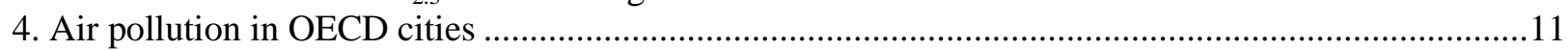

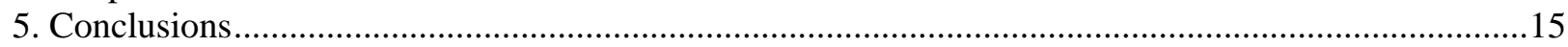

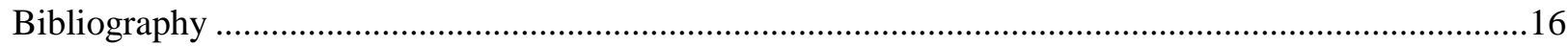

\section{Tables}

1. Advantages and disadvantage of the two main sources of data on air pollution.................................6

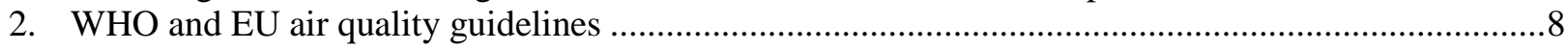

3. Pearson correlation between urban form and exposure to $\mathrm{PM}_{2.5}$ in OECD cities .............................15

\section{Figures}

1. Number of air quality $\left(\mathrm{PM}_{2.5}\right)$ monitoring stations per urban population in selected OECD countries, 2013

2. $\mathrm{PM}_{2.5}$ concentrations based on satellite-based data, 2011 ................................................................

3. Average exposure to PM2.5 in OECD and non OECD countries (2002 to 2011) .............................8

4. Average exposure to PM2.5 in OECD countries and selected non-OECD countries (2002 and 2011)..........9

5. Regional disparities in average exposure to air pollution, 2011 .................................................10

6. Number of deaths due to air pollution and average exposure to air pollution in OECD countries ......11

7. Average exposure to PM2.5 in OECD cities (right axis) and share of urban population exposed to

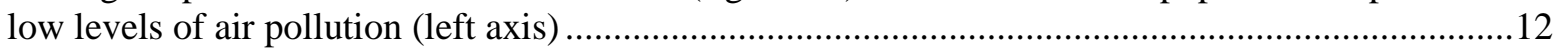

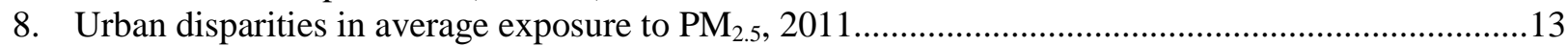

9. Share of urban population with exposure to $\mathrm{PM}_{2.5}$ below the national average (2011) .....................13

10. Average population exposure to PM2.5 and population density in OECD cities (2011)...................14

11. Average exposure to PM2.5: Asia and Oceania, 2011 ..................................................................19

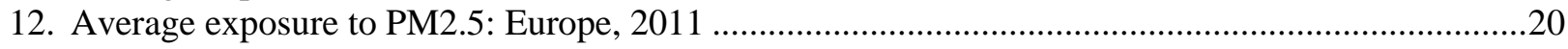

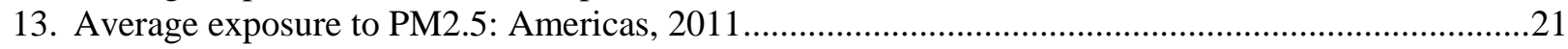

14. Average exposure to PM2.5: Emerging economies, 2011 ..............................................................22 


\section{Introduction}

The impact of outdoor air pollution on people's health is sizeable. Fine particulate matter (or $\mathrm{PM}_{2.5}$, 2.5 microns and smaller), a mixture of sulphates, nitrates, ammonia, sodium chloride, carbon, mineral dust and water suspended in the air, can cause respiration and cardiovascular morbidity or mortality from lung cancer, cardiovascular and respiratory diseases (World Health Organisation- WHO, 2013; European Environmental Agency, 2012). Recent estimates put the global toll of deaths from outdoor air pollution to over 3 million in 2012; almost 90\% of these deaths occurred in low and middle income countries (WHO, 2014). International guidelines on the concentration of fine particulate matter in the air that are dangerous to public health have been set since 2005 by the WHO and 2008 in the European Union (WHO, 2006; EU, 2008).

Fine particulate matters are emitted from the combustion of liquid and solid fuels for industrial and housing energy production, vehicles and biomass burning in agriculture. Air pollution is greatly associated with industry, urbanisation and transport; however, evidence shows that in developing countries the contribution of biomass burning from agriculture and from household cooking to local and regional air pollution is sizeable (Environmental Performance Index, 2014). Thus, exposure to air pollution, and its causes, may vary greatly whether people live in cities or in rural areas, in developed or developing countries. In OECD countries and fast urbanising countries, exposure to air pollution is mainly an urban issue that requires measures and policies targeted to these areas.

The quality of the environment, and in particular air pollution for its negative impact on health, is also a determinant of individual well-being, life satisfaction and location choice (White, 2013; Ferreira, 2013; Button and Rietveld; 1999). The OECD framework to measure regional well-being emphasises the dynamics between individual well-being and place-based characteristics (OECD, 2014a); it includes the environmental dimension through the indicator of average exposure to air pollution in a region described below.

Notwithstanding the importance of location to assess environmental outcomes, internationally comparable measures of air pollution at the sub-national and national level are rather limited and a comprehensive dataset of air pollution in cities is lacking. The contribution of this paper is threefold. First, a new set of estimates of exposure to air pollution (fine particulate matter - $\mathbf{P M}_{2.5}$ ) are computed at the city, regional and national levels for the 34 OECD countries, and at the regional and national levels for Brazil, China, India, Russia and South Africa. The estimates, produced for the OECD work to measure regional well-being (OECD, 2014a), are derived by the computation of satellite-based observations by van Donkelaar et al. (2014). They have the advantage of providing consistent values of the magnitude and spatial distribution of air pollution to be compared across and within countries. Second, the trends of population exposure to air pollution in the last decade are presented, to inform whether improvements on environmental and health outcomes have happened with respect to international standards. Third, we focus on the quality of air in the OECD cities and explore the association between size, density and shape of cities and air pollution. The urban form can indeed have an impact on air quality, whether a city is densely populated, its inhabitants commute long distance, road vehicles are the main transportation mode for people and freight, etc. While this analysis is exploratory and other possible determinants of air pollution should be included, this paper focuses on morphological characteristics of cities since it makes use of a common definition of functional urban areas that allows to measure the extension of built-up areas in a city and distinguish between the core part of a city and its commuting zone ${ }^{2}$ (OECD, 2012a). The estimates

2. The definition of functional urban areas has been developed by the OECD and European Union: Using population density and travel-to-work flows as key information, urban areas are identified as being characterised by densely inhabited "city" and less-populated municipalities whose labour market is highly integrated with the cores ('commuting zone'). Details of the methodology to identify functional urban areas can be found in OECD (2012) "Redefining Urban: A new way of measuring metropolitan areas”. 
provided in the paper can offer a novel insight into a way to quantify air pollution at the sub-national level and provide tailored information to policymakers to design and implement policy responses.

The results show that while air quality at national and local level has generally improved in OECD countries in the past decades, thanks to the introduction of regulatory and policy instruments ${ }^{3}$, a significant proportion of population live in regions where air pollution still exceeds air quality standards In 209 out of the 362 OECD regions people are on average exposed to levels of air pollution higher than the World Health Organisation recommended pollution concentration level. In the non-OECD countries included in this paper, the concentration of air pollution remains high in China and India and the tendency has been to increase over the past decade. Results also show 68\% of the urban population in OECD countries are exposed to dangerous levels of air pollution. Finally, from a preliminary exploratory analysis a positive, although small, correlation between air pollution concentration and the density of urban population or the share of built-up areas is found, a negative, also small, correlation with the extension of the commuting zone of cities, while there is no significant association between air pollution and the population size.

The rest of the paper is organised as follows. Section 2 describes the source of data and the methodology used to derive air pollution estimates at different territorial scales. It also provides a brief discussion on the advantages and disadvantages of using satellite data and geographic information system data. Section 3 provides an overview of the exposure of air pollution in OECD and non-OECD countries, and the extend of regional differences in the exposure to air pollution within countries. Regional and national values of exposure to air pollution in the past decades are compared to the thresholds recommended by the World Health Organization and the European Union. Section 4 presents the concentration of air pollution in the 275 OECD-EU metropolitan areas, showing in which countries air pollution is a major concern for cities. It then correlates the exposure to air pollution to some characteristics of cities, such as population density, size and extension of the city and its commuting shed, and share of built-up area. Section 5 concludes.

\section{Methodology and data}

Limited availability of data has hindered the assessment and comparison of air pollution at subnational levels. A major source of air pollution data comes from ground-based stations that are normally installed in cities. Ground-based stations provide the most accurate measure of local fine particulate matters and offer regular levels of air pollution over time. A major shortcoming is that coverage within OECD countries tends to be heterogeneous (Figure 1) and many developing countries lack the capacity to establish ground-based air pollution monitoring stations. Additionally, placement of monitors to represent air quality exceeds rather than typical conditions, as well as local differences in instrumentation and reporting can bias the representation of exposure from ground-based monitors for comparison between countries (EPI 2014). The most comprehensive dataset based on monitoring stations is the WHO Environment and Health Information System (ENHIS) that gathers population-weighted country-level exposure to PM and $\mathrm{PM}_{2.5}$ submitted by European countries to the European Environment Agency. The country levels are derived by data from urban or suburban monitoring stations for which these measurements are available for at least $75 \%$ of days in the year. However, according to the ENHIS, the assessment for several countries is based on data from one or few cities only, and in five countries the coverage of the urban population was $20 \%$ or less in 2011 (WHO- ENHIS, n.d.).

3. Chay and Greenstone (2005) find that total suspended particulates levels fell substantially in US counties after the federal government regulated the air pollution with the Clean Air Act Amendments (CAAAs) and the establishment of the Environmental Protection Agency (EPA) in 1970.Similarly, Wesselink et al (2006) find a significant impact on the reduction or air pollution caused by road transport in Europe due to the effect of sequential Euro emission requirements on particulate emissions from road traffic. 
Figure 1. Number of air quality $\left(\mathrm{PM}_{2.5}\right)$ monitoring stations per urban population in selected OECD countries, 2013

Number of monitoring stations per 1000000 urban population
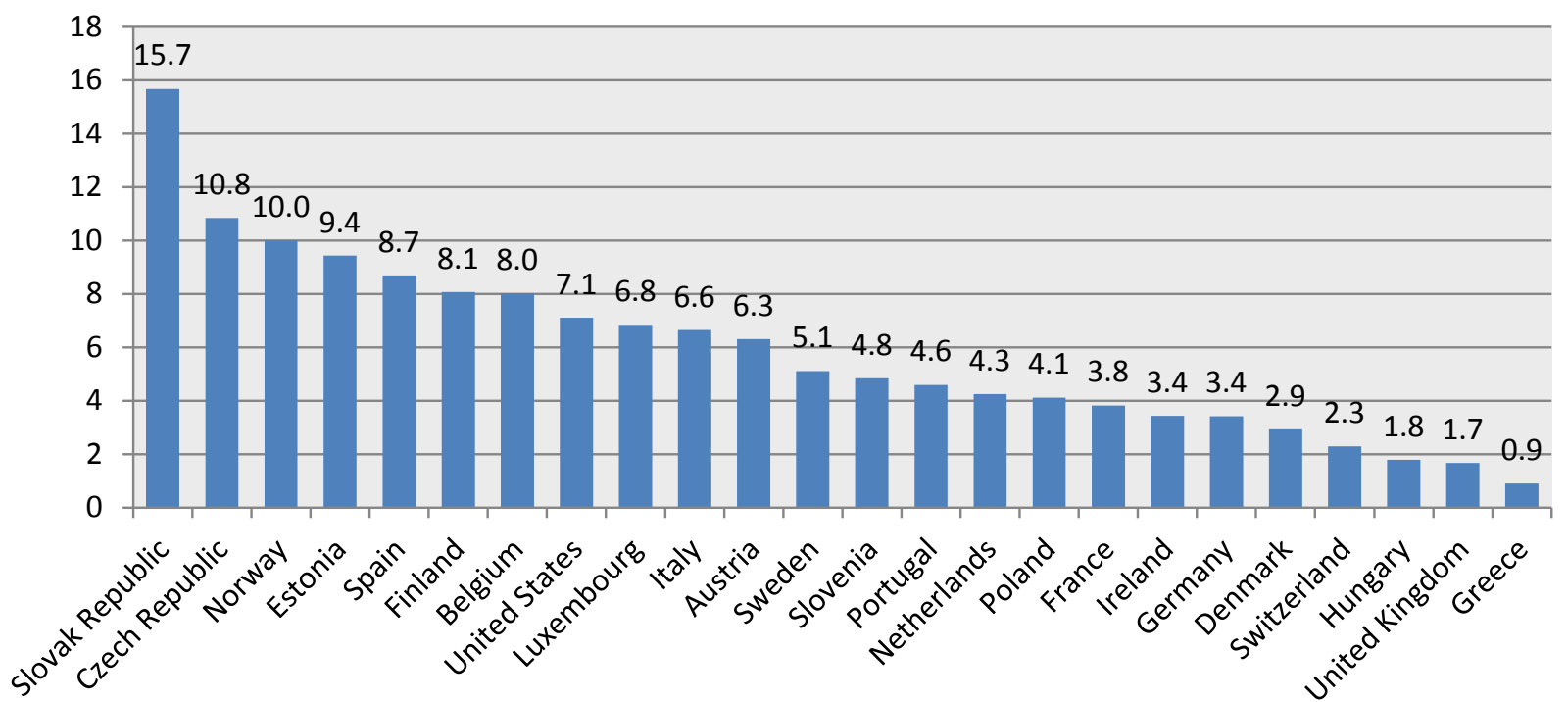

Note: The urban population in a country is defined as the total population residing in the OECD-EU functional urban areas.

Source: United States Environmental Protection Agency (http://www.epa.gov/airquality/airdata/ad maps.html) European Environment Agency. AirBase: public air quality database - Air pollution. Version 8. (http://www.eea.europa.eu/data-andmaps/data/airbase-the-european-air-quality-database-8 )

An additional source of data for air pollution consists of estimates derived from satellite observations, such as $\mathrm{PM}_{2.5}$ concentration. This paper uses these satellite-based estimates as an alternative source to monitor air pollution. These estimates are less precise than ground-based measurement, but have several advantages (Table 1). In particular, satellite-based estimates provide data in areas of the globe where air monitoring stations are not available or have a poor territorial coverage. Satellite data, moreover, provide consistent values using the same method and technology for different territories (EPI, 2014). In this paper the satellite-based data of global exposure to $\mathrm{PM}_{2.5}$ from multiple satellites with annual observations in the period 1998-2012 provided by van Donkelaar et al. (2014) are used to compile air pollution estimates at different geographical details.

Table 1.Advantages and disadvantage of the two main sources of data on air pollution

\begin{tabular}{|l|l|l|l|}
\hline Advantages & $\begin{array}{l}\text { Ground-based stations } \\
\text { Direct measures } \\
\text { Offer regular levels of air pollution } \\
\text { over time } \\
\text { More pollutants are available }\end{array}$ & $\begin{array}{l}\text { Satellite data } \\
\text { Global coverage } \\
\text { Consistent method to compute air } \\
\text { pollution in cities, regions and } \\
\text { countries } \\
\text { Consistent time-series data, spanning } \\
\text { more than a decade }\end{array}$ \\
\hline Disadvantages & $\begin{array}{l}\text { Low coverage in developing countries } \\
\text { - Uneven coverage within and across } \\
\text { countries }\end{array}$ & $\begin{array}{l}\text { Modelled data } \\
\text { PM2.5 concentration rarely monitored } \\
\text { Site selection, measurement } \\
\text { techniques, and reporting methods } \\
\text { differ across regions and countries }\end{array}$ & $\begin{array}{l}\text { Satellite observations are less precise } \\
\text { for bright surfaces (snow or desert) } \\
\text { Current data are on a multi-year } \\
\text { average, evaluation of short-term } \\
\text { events often unavailable }\end{array}$ \\
\hline
\end{tabular}


The estimated average exposure to air pollution $\left(\mathrm{PM}_{2.5}\right)$ is based on GIS-based methodology at city, regional and national levels using the satellite-based $\mathrm{PM}_{2.5}$ estimates of van Donkelaar et al. (Figure 2) at $0.1^{\circ} \times 0.1^{\circ}$ geographic grid resolution. The method used to produce the estimates is the following: the satellite-based of air pollution at $1 \mathrm{~km}^{2}$ are multiplied by the population living in that area (using a $1 \mathrm{~km}^{2}$ resolution population grid). The exposure to air pollution in a region (or city or country) is given by the sum of the population weighted values of $\mathrm{PM}_{2.5}$ in the $1 \mathrm{~km}^{2}$ grid cells falling within the boundaries of the region (city or country). Finally, the average exposure to $\mathrm{PM}_{2.5}$ concentration in a region is given by dividing this aggregated value by the total population in the region. A similar method was previously applied by the OECD to other environmental indicators derived by global databases and geographical sources (Piacentini and Rosina, 2012). The advantages of this method in producing air pollution estimates at city level are: the fine resolution of the satellite input data and the fact that the boundaries of cities are defined in a consistent way across OECD countries, through a functional definition that includes the densely populated urban cores and their commuting shed (OECD, 2012a). In particular, using the OECD/EU definition of functional urban areas overcomes previous limits of identification of all cities, such as in the Global Model of Ambient Particulates (GMAPS) developed by the World Bank (Cohen et al., 2004). ${ }^{4}$

Figure 2. $\quad \mathrm{PM}_{2.5}$ concentrations based on satellite-based data, 2011

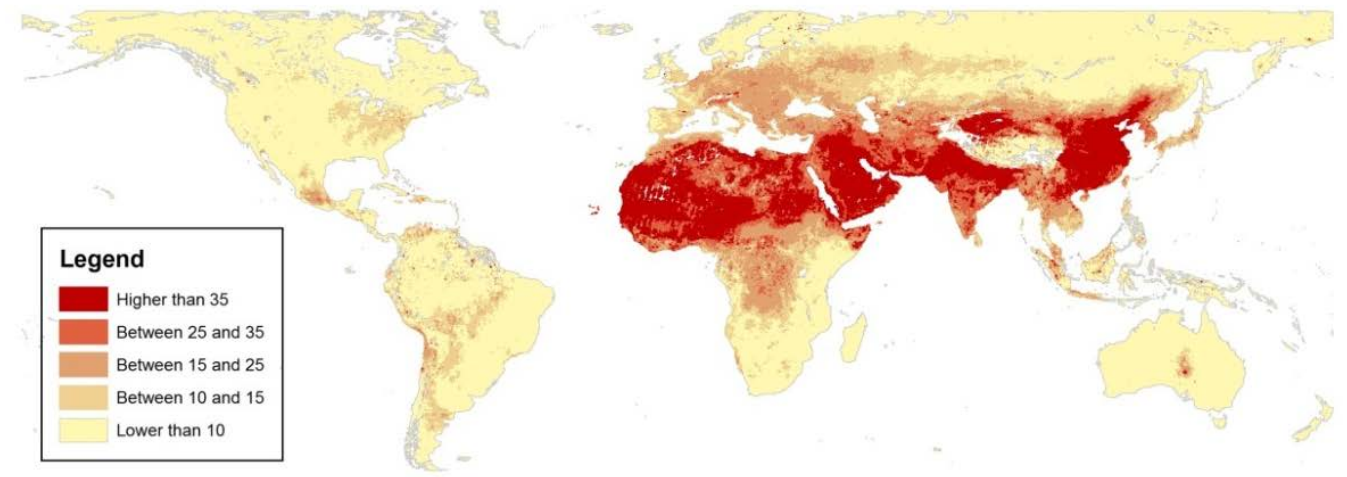

Note: The data refer to three-year average (2010-2012). The 50\% relative humidity standard has been adopted for consistency with the ground-level measurements. The map displays $\mathrm{PM}_{2.5}$ concentrations according to five levels based on the WHO guidelines.

Source: van Donkelaar, A., R. V. Martin, M. Brauer and B. L. Boys (2014) "Use of Satellite Observations for Long-Term Exposure Assessment of Global Concentrations of Fine Particulate Matter". Environmental Health Perspectives, in press.

\section{Levels and trends of $\mathbf{P M}_{2.5}$ in OECD regions}

In the past ten years air quality has generally improved in OECD countries, the average exposure to $\mathrm{PM}_{2.5}$ has decreased by 17 percentage points (from $15 \mu \mathrm{g} / \mathrm{m}^{3}$ in 2002 to $12.4 \mu \mathrm{g} / \mathrm{m}^{3}$ ) in 2011 (Figure 3). The reduction in air pollution in OECD countries is mainly due to the adoption of emission controls on vehicles (OECD 2014b) and policy and regulatory instruments imposed at international, national and local levels (Baldasano et al. 2003). However in the same period, the average concentration levels of air pollution in non OECD countries increased from $29 \mu \mathrm{g} / \mathrm{m}^{3}$ in 2002 to $34.2 \mu \mathrm{g} / \mathrm{m}^{3}$ in 2011, strongly influenced by the high exposure levels observed in India and China (Figure 3). According to the 2014

4. The GMAPS model is used to generate estimates of concentrations of PM10 in 3226 cities with a population larger than 100 000. The GMAPS model uses the latest available data from a sample of cities from the World Health Organization (WHO) and other sources and then uses regression estimates to predict PM concentrations worldwide. Although this database provides PM concentrations worldwide using the same methodology, it includes only a number of cities and does not cover all the territory. 
Environmental Performance Index the number of people breathing unsafe air totals 1.78 billion, or one quarter of the global population, three times higher the number of people exposed to air pollution in 2000, due to urbanisation and the expansion of industry and fossil fuels-based transportation sectors in the developing world (EPI, 2014).

Figure 3. Average exposure to PM2.5 in OECD and non OECD countries (2002 to 2011)

$$
\mu \mathrm{g} / \mathrm{m}^{3} \quad \square \mathrm{OECD} \square \text { rest of the world }
$$

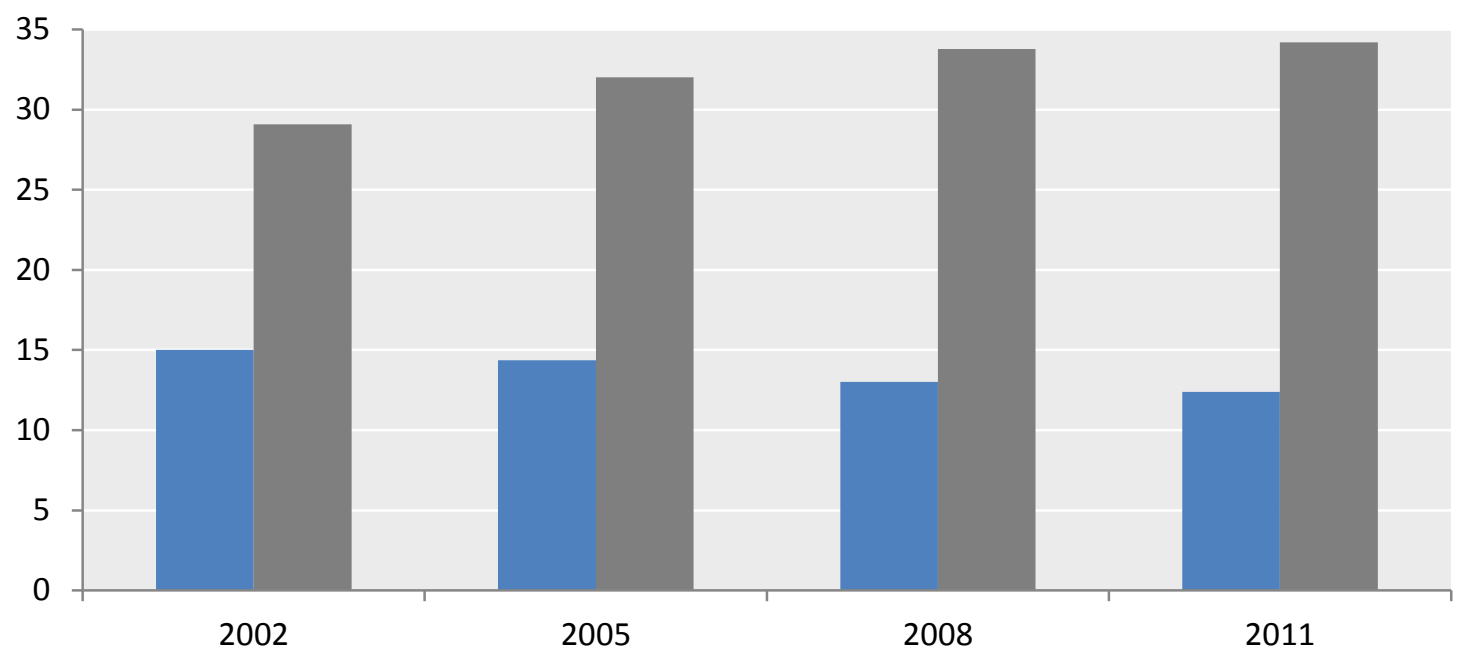

Note: Data refer to three-year average measures (2001-2003, 2004-2006, 2007-2009 and 2010-2012) aggregate for OECD and nonOECD countries.

Source: OECD calculations based on van Donkelaar et al. (2014).

Since 2005 the World Health Organisation has introduced air quality guidelines, identifying unsafe $\mathrm{PM}_{2.5}$ concentration values based on their association to morbidity and mortality risk (Table 2). Similarly, the European Union has established an exposure concentration obligation for European countries which has been set at a maximum of $20 \mu \mathrm{g} / \mathrm{m}^{3}$ to be meet by 2015 .

Table 2.WHO and EU air quality guidelines

\begin{tabular}{|c|c|c|}
\hline $\mathrm{PM}_{2.5} \mu \mathrm{g} / \mathrm{m}^{3}$ & $\begin{array}{l}\text { WHO guidelines associated to morbidity and } \\
\text { mortality risk }\end{array}$ & $\begin{array}{l}\text { EU concentration } \\
\text { obligation }\end{array}$ \\
\hline 10 & $\begin{array}{l}\text { Air quality concentration exposure above this level } \\
\text { increase the probability to have cardiopulmonary and } \\
\text { long term mortality. } \\
\text { In addition to other health benefits, these levels lower } \\
\text { the risk of premature mortality by approximately } 6 \% \\
\text { relative to the } 25 \mu \mathrm{g} / \mathrm{m}^{3} \text { level. }\end{array}$ & \\
\hline 20 & & $\begin{array}{l}\text { Exposure concentration } \\
\text { obligation to be meet by } \\
2015\end{array}$ \\
\hline 25 & $\begin{array}{l}\text { In addition to other health benefits, these levels lower } \\
\text { the risk of premature mortality by approximately } 6 \% \\
\text { relative to the } 35 \mu \mathrm{g} / \mathrm{m}^{3} \text { level. }\end{array}$ & \\
\hline 35 & $\begin{array}{l}\text { Levels associated with about a } 15 \% \text { higher long-term } \\
\text { mortality risk relative to } 10 \mu \mathrm{g} / \mathrm{m}^{3} \text { level. }\end{array}$ & \\
\hline
\end{tabular}

Note: These guidelines refer to annual mean concentrations.

Source: WHO (2006) and EU (2008) 
Average exposure to $\mathrm{PM}_{2.5}$ levels decreased in 31 out of 34 OECD countries between 2002 and 2011, with the exception of Israel (from $19.7 \mu \mathrm{g} / \mathrm{m}^{3}$ to $22.7 \mu \mathrm{g} / \mathrm{m}^{3}$ ), New Zealand (from $2.1 \mu \mathrm{g} / \mathrm{m}^{3}$ to 2.3 $\mu \mathrm{g} / \mathrm{m}^{3}$ ) and Turkey (from $17.0 \mu \mathrm{g} / \mathrm{m}^{3}$ to $18.3 \mu \mathrm{g} / \mathrm{m}^{3}$ ). In 2011, exposure to $\mathrm{PM}_{2.5}$ levels ranged on average between $23.8 \mu \mathrm{g} / \mathrm{m}^{3}$ in Korea and $2.3 \mu \mathrm{g} / \mathrm{m}^{3}$ in New Zealand. Twenty-one OECD countries were still above the WHO recommended concentration level of $10 \mu \mathrm{g} / \mathrm{m}^{3}$ and Korea and Israel above $20 \mu \mathrm{g} / \mathrm{m}^{3}$. Among the non-OECD countries considered, China and India have exposure to pollution four times higher than OECD levels and has been on the rise in the past ten years (Figure 4).

Figure 4. Average exposure to PM2.5 in OECD countries and selected non-OECD countries (2002 and 2011$)$

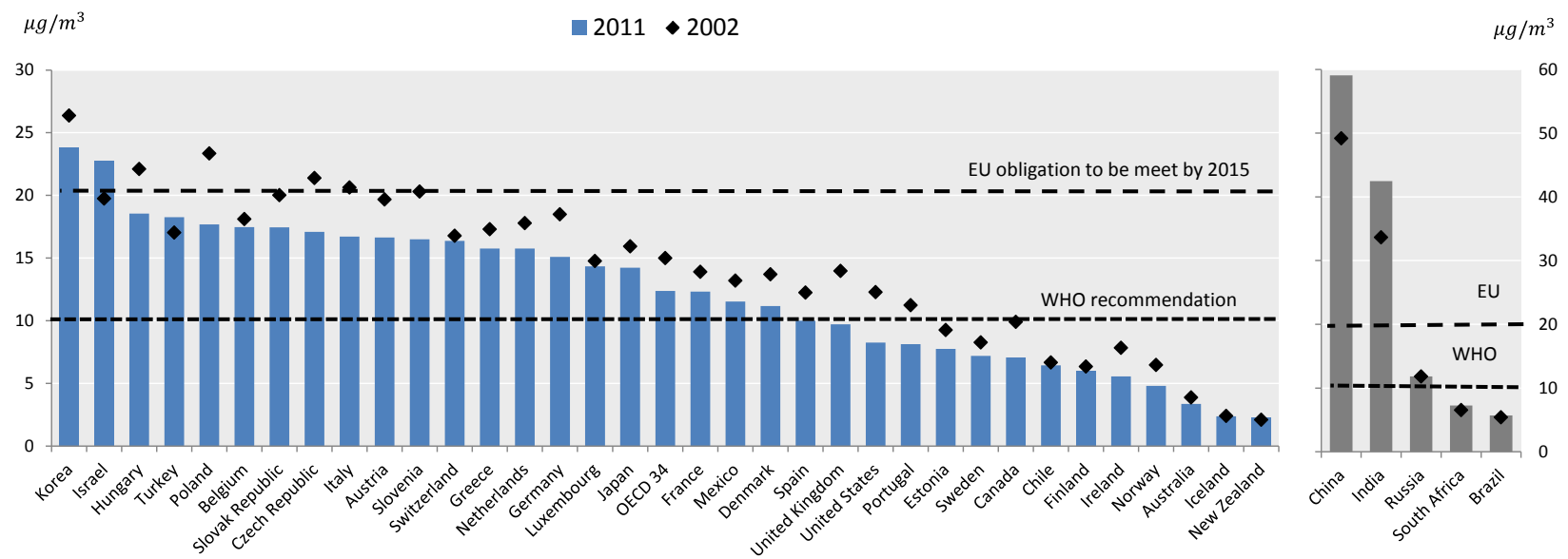

Note: Data refer to three-year average measures (2001-2003 and 2010-2012).

Source: OECD calculations based on van Donkelaar et al. (2014).

OECD estimates show wide variation in $\mathrm{PM}_{2.5}$ exposure levels across regions within countries, the largest in Mexico, Italy, Chile and Turkey (Figure 5). According to 2011 estimates, in 58\% of the OECD regions, representing $64 \%$ of the total OECD population, the levels of air pollution were higher than the World Health Organization's recommended concentration of $10 \mu \mathrm{g} / \mathrm{m}^{3}$. Critically high values are found in some regions in Korea, Turkey, Mexico, Italy and Israel, among the OECD countries, and China and India in non OECD countries (Figure 5 and Annex A). For example, For example, Chile shows a national average exposure to $\mathrm{PM}_{2.5}$ of $6.4 \mu \mathrm{g} / \mathrm{m}^{3}$, which is comparatively low; however, in four out of fifteen regions, air pollution levels are higher than the recommended value of $10 \mu \mathrm{g} / \mathrm{m}^{3}$. The set of air pollution estimates are publicly available via the OECD Regional Well-Being database [http://dx.doi.org/10.1787/region-data-en]. 
Figure 5. Regional disparities in average exposure to air pollution, 2011

Regions with the lowest and highest exposure to $\mathrm{PM}_{2.5}$ levels

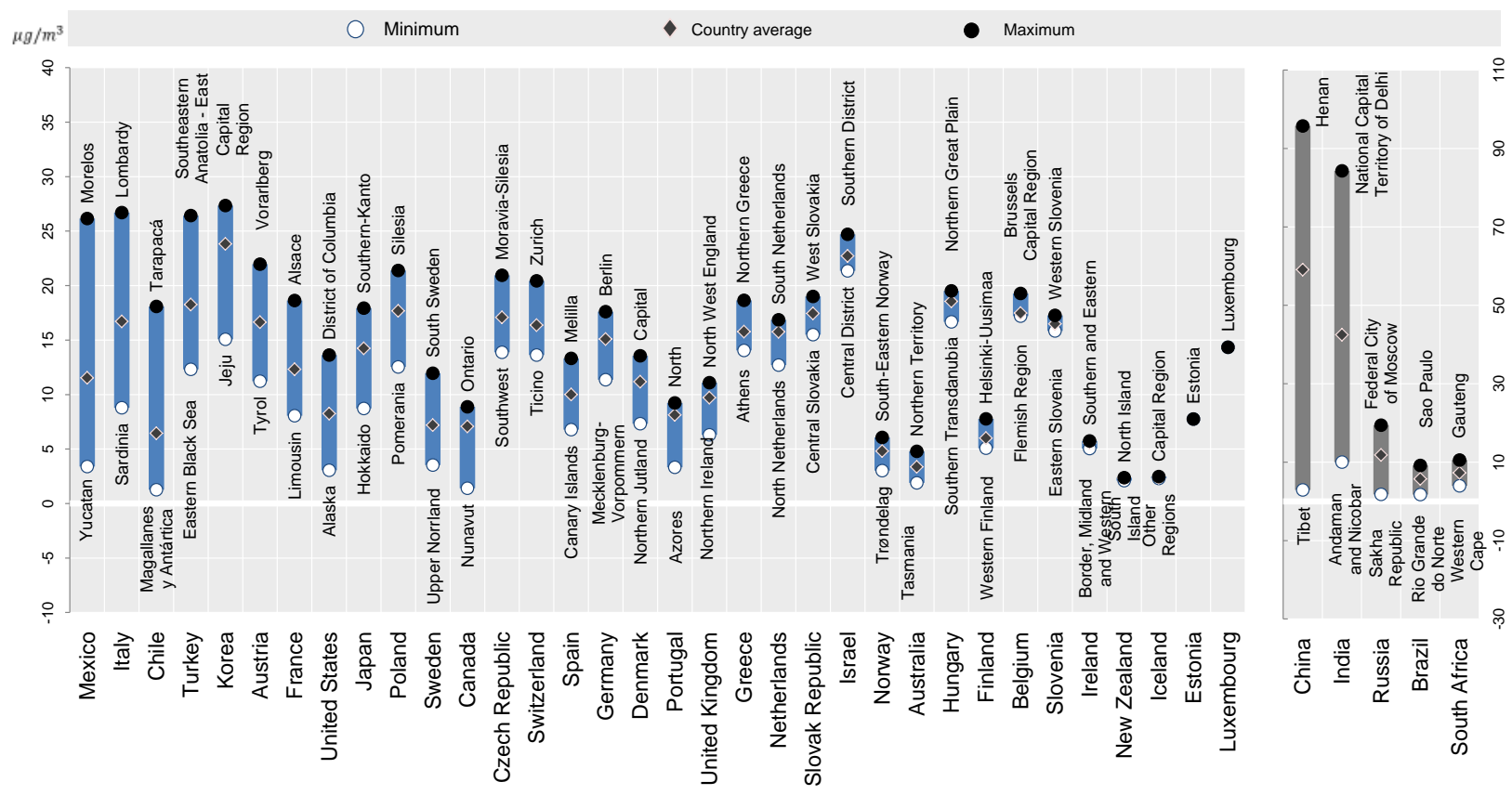

Note: Data refer to three-year average measures (2010-2012).

Source: OECD calculations based on van Donkelaar et al. (2014).

Exposure to air pollution where it happens, in the region or city where people live, is an important aspect of people's well-being (OECD, 2014a). The exposure to fine particulate matters, considered one of the pollutants to have the greatest impact on people's health, reduces life expectancy between 8 months up to two years in the most polluted places (EEA, 2012), and it has become the main environmental cause of premature death overtaking other environmental causes such as lack of sanitation and clean drinking water (OECD, 2014b). Figure 6 shows a strong correlation between past exposure to $\mathrm{PM}_{2.5}$ and present deaths due to air pollution in OECD countries. Indeed, in 2010 ambient particulate matter pollution caused on almost 500000 deaths, and East European countries such as Poland, Czech Republic, Slovak Republic and Hungary display the largest mortality rates and exposure to air pollution levels among the 34 OECD countries. Environmental issues have also been shown to have an economic impact. A recent study estimates that OECD countries are willing to pay USD 1.7 trillion to avoid deaths caused by air pollution (OECD, 2014b). Silva and Brown (2013) show that the impact of decreasing average annual particulate matter concentrations by $1 \%$ is equivalent to increasing per capita income by $0.71 \%$. 
Figure 6. Number of deaths due to air pollution and average exposure to air pollution in OECD countries

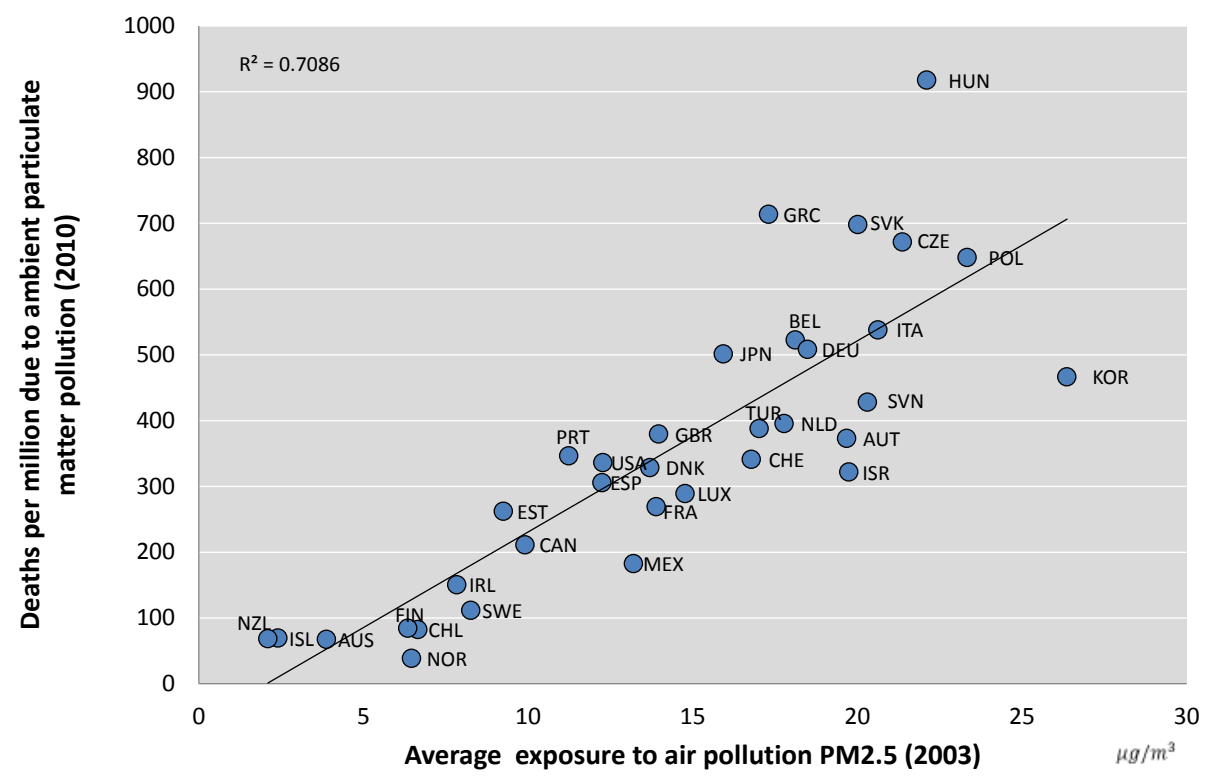

Note: Population exposure to air pollution refers to three-year average (2001-2003).

Source: Authors calculations from van Donkelaar et al. (2014) and database on deaths for environmental causes by the Institute for Health Metrics and Evaluation http://vizhub.healthdata.org/gbd-compare.

\section{Air pollution in OECD cities}

The concentration of people, activity and emissions from different sources calls for policy interventions and the continuous monitoring of air quality in cities. However, the availability of groundmonitoring stations and the monitoring methods are quite differentiated even among OECD countries. ${ }^{5}$ Moreover, comparisons of air pollution in cities may be biased by the definition of city to which these values refer. In order to estimate the average exposure to air pollution, we make use of a harmonised definition of functional urban areas that identifies 275 cities with a population above 500000 inhabitants across 29 OECD countries and apply to them the satellite-based $\mathrm{PM}_{2.5}$ data to estimate. ${ }^{6}$ Exposure to air pollution in OECD cities has decreased by 19 percentage points (from $16 \mu \mathrm{g} / \mathrm{m}^{3}$ in 2003 to $13 \mu \mathrm{g} / \mathrm{m}^{3}$ in 2011 (right axis in Figure 7). However, only 32\% of the urban population in OECD countries, or 174 million people, are exposed to pollution below the World Health Organization's recommended level of 10 $\mu \mathrm{g} / \mathrm{m}^{\wedge} 3$ in 2011 (Figure 7). This share is equal to 14\% and 4\%, respectively, in European and Japanese cities.

5. The World Health Organization has recently released the first "air pollution in cities" database whose values derive from ground monitoring stations. The database includes 1600 cities in 91 countries and gathers data on PM concentration collected through publicly available national or subnational reports, website or monitoring ground station in urban areas. See http://www.who.int/phe/health_topics/outdoorair/databases/cities/en/

6. The OECD-EU definition of functional urban areas has not been applied to Australia, Iceland, Israel, New Zealand and Turkey. For simplicity we refer here to cities as the 275 OECD-EU functional urban areas with a population larger than 500000 people. For details on the method to identify the functional urban areas, see OECD 2012. 
Figure 7. Average exposure to PM2.5 in OECD cities (right axis) and share of urban population exposed to low levels of air pollution (left axis)

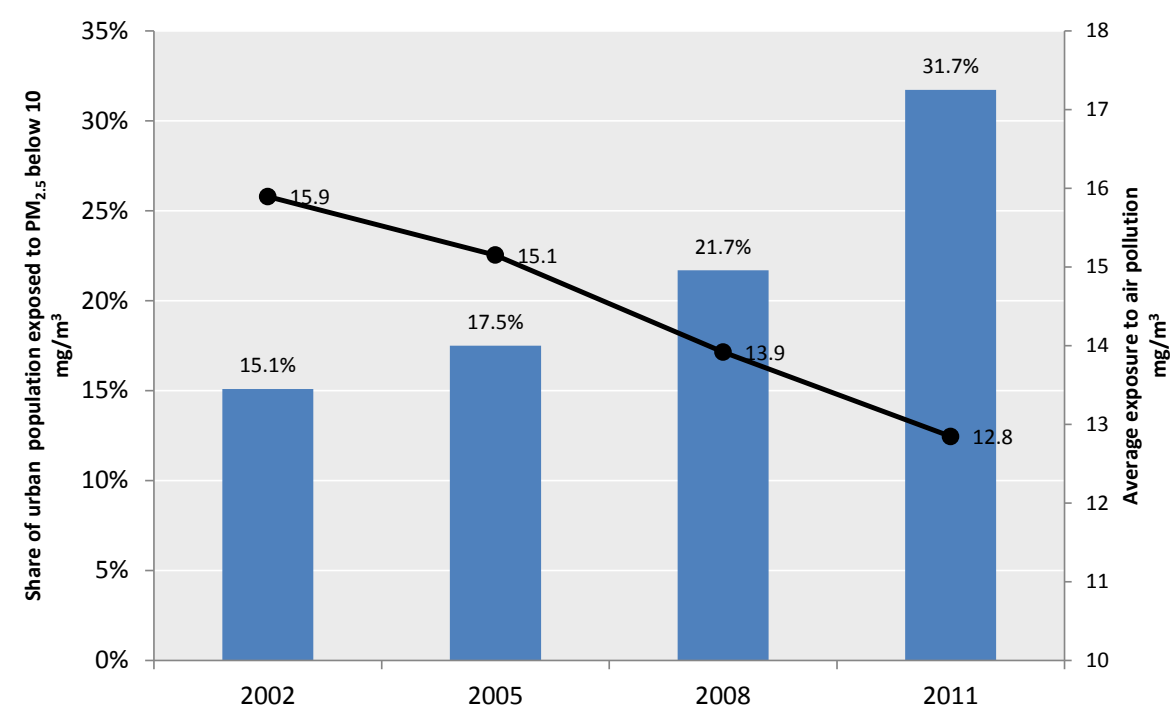

Note: Data refer to three-year average measures (2001-2003, 2004-2006, 2007-2009 and 2010-2012)

Source: OECD calculations based on van Donkelaar et al. (2014).

Because of the geographical concentration of people, economic activities and emissions from different sources, cities have usually higher air pollution than the rest of the country. However, due to cities' characteristics, (such as climate, altitude, density of population, extension, transportation network, economic activities, etc.) and local efforts to reduce air pollution, (through regulations and policy instruments on transport, energy and economic activities), the quality of the air can vary largely also across cities in the same country. For example, the average exposure to $\mathrm{PM}_{2.5}$ in Cuernavaca (Mexico), Milan (Italy) and Kurnamoto (Japan) is three times higher than in other cities of the same country, while all cities in Canada, Finland, Chile, Estonia, Norway and Ireland have relatively low level of air pollution (Figure 8). 
Figure 8. Urban disparities in average exposure to $\mathrm{PM}_{2.5}, 2011$

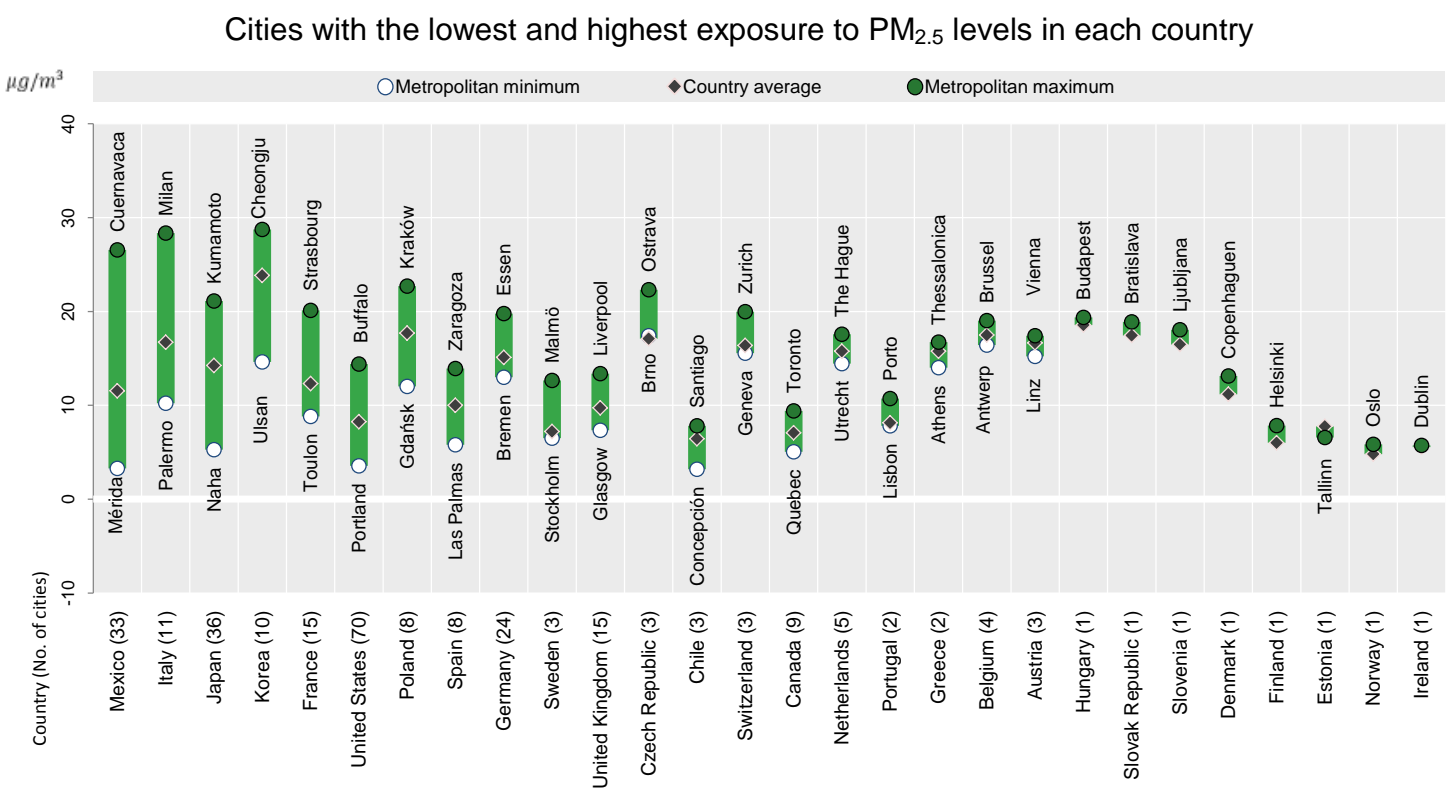

Note: Data refer to three-year average measures (2010-2012). The cities included are the OECD-EU functional urban areas with a population larger than 500000 people.

Source: OECD calculations based on van Donkelaar et al. (2014).

In the Czech Republic, Denmark, Finland, Hungary, Ireland, Norway, Slovenia and the Slovak Republic, the entire population living in urban areas is exposed to pollution levels above the national average. However, on average in the OECD area 30\% of urban population is exposed to lower level of air pollution than non-urban population. At country level, the share of urban population exposed to lower levels of air pollution than the rest of the country varies from 100\% in Estonia to 10\% in Spain (Figure 9).

Figure 9. Share of urban population with exposure to $\mathrm{PM}_{2.5}$ below the national average (2011)

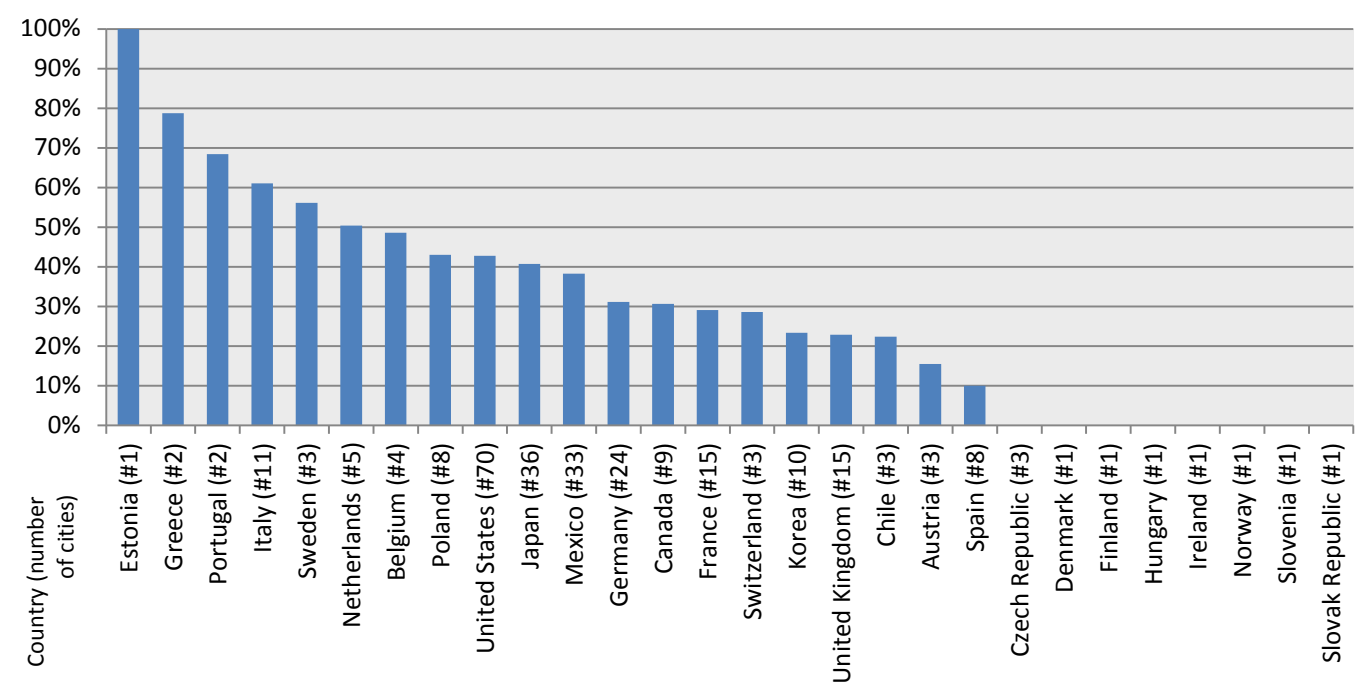

Note: Data refer to three-year average measures (2010-2012)

Source: OECD calculations based on van Donkelaar et al. (2014). 
Cities are one of the largest consumers of energy and thus one of the main sources of carbon emissions. Roughly two-thirds of all emissions in the United States come from electricity and road transport activities in urban and intermediate regions, with an additional one-quarter produced by industrial and residential uses (Kamal-Chaoui and Robert, 2009). The size, shape (whether a city is densely populated, its inhabitants commute long distance, etc.) and uses of land in cities can have an impact on emissions and air pollution. Higher population density might reduce energy consumption, limit private motorized trips and promote public transportation, thus reducing emissions and improving air quality in the long run (OECD, 2012b). $\mathrm{CO}_{2}$ emissions per capita in cities are generally lower in densely populated places (OECD 2013). Similarly, compact cities are found to be more efficient in energy use and transport, with a positive impact on decreasing greenhouse gas emissions (Satterthwaite, 1999; Gottdiener and Budd, 2005). However, a higher density of people and activities increases the exposure of individuals to air pollution, and therefore a static positive relation between air pollution and population density is expected.

The preliminary analysis of the correlation between exposure to $\mathrm{PM}_{2.5}$ in cities and some indicators of urban form finds a small positive relation between population density and higher exposure of individuals to concentrations of fine particulate matter (Figure 10), supporting previous results that link denser cities to higher traffic congestions and thus higher exposure to PM concentrations (Manins et al., 1998; Gaigne et al., 2012; Martins et al. 2012). ${ }^{7}$ Figure 10 might also suggest that people in very densely populated cities (with more than 2000 inhabitants per $\mathrm{km}^{2}$ ) benefit from decreasing marginal costs of pollution. ${ }^{8}$

Figure 10. Average population exposure to PM2.5 and population density in OECD cities (2011)

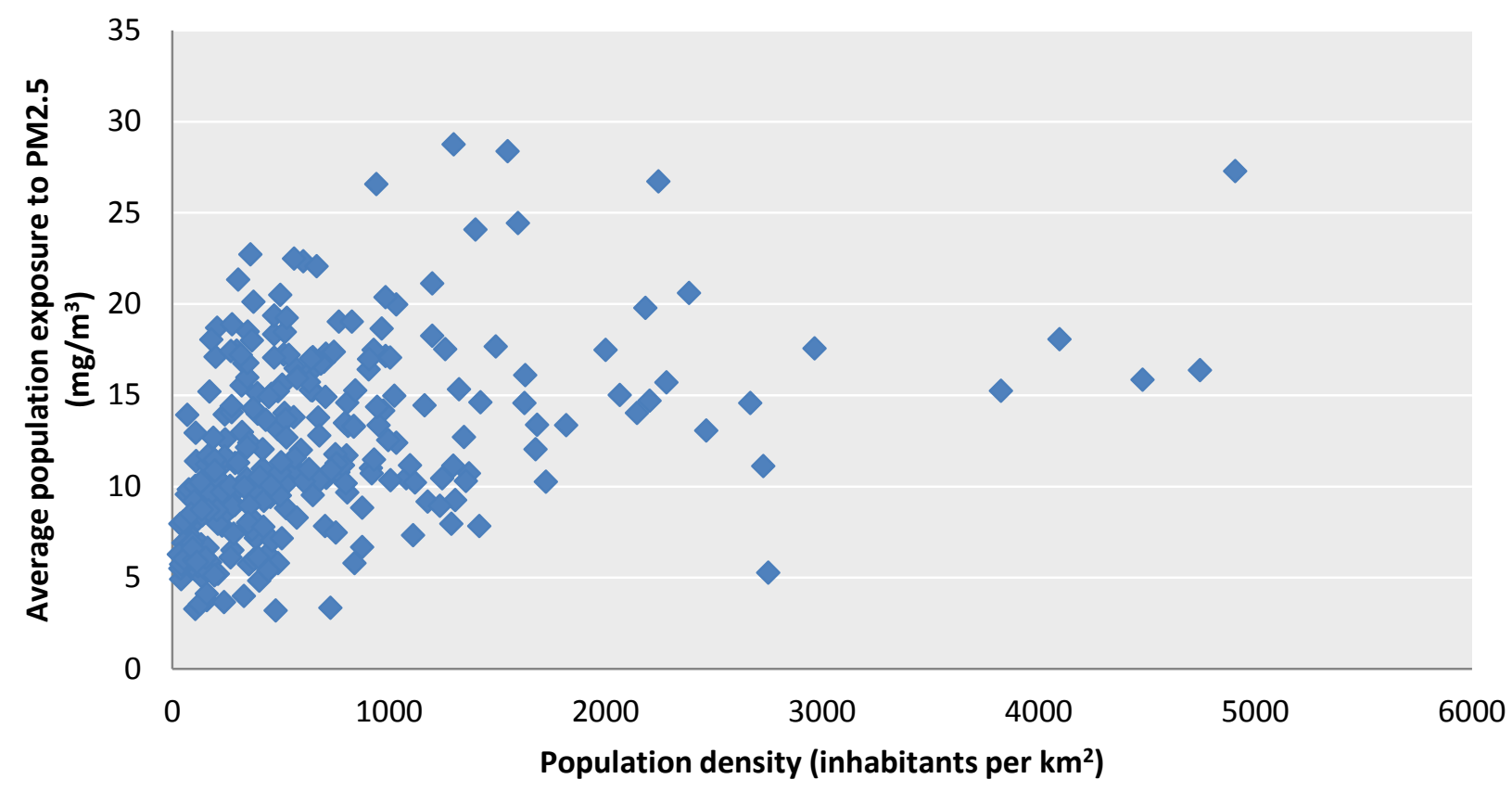

Note: Air pollution data refer to three-year average measures (2010-2012)

Source: OECD calculations based on Metropolitan database and van Donkelaar et al. (2014).

7. The diversity of $\mathrm{PM}_{2.5}$ sources, including power plants, biomass burning, biofuel burning and mineral dust, adds complexity to the relation between $\mathrm{PM}_{2.5}$ and urban form.

8. To test whether the results of figure 10 depend on the different land extensions of the defining building blocks of the functional urban areas, we have computed an alternative population density index using the population density of each grid cell weighted by the total population of the grid cells belonging to the city. The results of figure 10 are unchanged. 
Pearson correlation analysis finds a positive correlation between air pollution (exposure to $\mathrm{PM}_{2.5}$ ) and the population density of cities and the extension of the commuting area compared to the city total area (Table 3). A small negative association is found between air pollution and the share of built-up areas in a city, while no significant association is found between air pollution and population size. These preliminary results need to be further tested controlling for other characteristics of cities. However, they underscore a tension between the collective economic and environmental benefits a densely populated area brings (for example vicinity of economic activities, thickness of skills and labour networks, reduction of carbon emissions, etc.) and the individual cost of living in places more exposed to air pollution. Integrated policies at local level - for example on land and housing markets, transport system, or planning of green spaces should help manage the trade-offs.

Table 3. Pearson correlation between urban form and exposure to $\mathrm{PM}_{2.5}$ in OECD cities

\begin{tabular}{|c|c|c|c|c|c|}
\hline & $\begin{array}{c}\text { Exposure to } \\
\mathrm{PM}_{2.5}\left(\mu \mathrm{g} / \mathrm{m}^{3}\right)\end{array}$ & $\begin{array}{c}\text { Population size } \\
\text { (No. of } \\
\text { inhabitants) }\end{array}$ & $\begin{array}{c}\text { Population } \\
\text { density } \\
\text { (inhabitants per } \\
\mathrm{km}^{2} \text { ) }\end{array}$ & $\begin{array}{l}\text { Share of } \\
\text { commuting zone } \\
\text { over total city } \\
\text { area }(\%)\end{array}$ & $\begin{array}{l}\text { Share of built-up } \\
\text { area over total } \\
\text { city area }(\%)\end{array}$ \\
\hline $\begin{array}{l}\text { Exposure to } \\
\mathrm{PM}_{2.5}\left(\mu \mathrm{g} / \mathrm{m}^{3}\right)\end{array}$ & 1 & & & & \\
\hline $\begin{array}{l}\text { Population size } \\
\text { (No. of } \\
\text { inhabitants) }\end{array}$ & 0.086 & 1 & & & \\
\hline $\begin{array}{l}\text { Population } \\
\text { density } \\
\text { (inhabitants per } \\
\mathrm{km}^{2} \text { ) }\end{array}$ & $0.405 * * *$ & $0.470 * * *$ & 1 & & \\
\hline $\begin{array}{l}\text { Share of } \\
\text { commuting zone } \\
\text { over total city } \\
\text { area }(\%)\end{array}$ & $0.264 * * *$ & $-0.148 * *$ & $-0.175 * * *$ & 1 & \\
\hline $\begin{array}{l}\text { Share of built-up } \\
\text { area over total } \\
\text { city area (\%) }\end{array}$ & $-0.205^{* * *}$ & $0.626 * * *$ & -0.037 & $-0.245 * * *$ & 1 \\
\hline
\end{tabular}

\section{Conclusions}

Air pollution has a significant negative impact on people's health and well-being. While the effects of air quality are felt locally, policy capacity to address environmental issues can be constrained by lack of relevant information at the local level. In this paper we suggest a novel way to quantify air pollution at subnational level based on satellite data and GIS-based methodologies. These estimates are made possible by recent significant improvements in global air quality monitoring from satellite data. The method has the advantages of a) providing a coherent set of estimates of exposure to air pollution at city, regional and national levels for the OECD countries; and b) providing values over time to monitor changes in air quality.

Our results show that air quality has improved in OECD countries in the past decades. However, there is still a room for improvement, since high levels of air pollution are found in some regions and cities. Results show that $68 \%$ of the urban population in OECD countries is exposed to dangerous levels of air pollution and few cities have been able to reduce the level of air pollution below the national average. Finally, we analyse the association between the shape of cities and the average exposure to $\mathrm{PM}_{2.5}$ for the first time at the global level. Preliminary results show a positive but weak association between air pollution and population density or the share of built-up areas, a negative but also small association with the extension of the commuting zone of cities, while no significant association has been found between air pollution and population size. Empirical analysis is still limited at the global level, and this exploratory 
analysis is a first step towards more extensive studies on the effect of urban form on environment outcomes. This study can be extended by analysing the relationship between the urban structure and the air pollution with a more extensive set of environmental indicators such as direct or indirect greenhouse gas emissions $\left(\mathrm{CO}_{2} . \mathrm{NO}_{2}, \mathrm{SO}_{2}\right.$, among others) and considering other non-environmental variables characterising the cities. Additionally, future developments should include a comparison between the air quality estimates based on satellite data to the values derived from monitoring-based stations, where available, to assess differences more precisely

\section{BIBLIOGRAPHY}

Baldasano, J.M., E. Valera and P. Jiménez (2003), “Air quality data from large cities”. The Science of the Total Environment, 307, pp. 141-165.

Button, K.J. and P. Rietveld (1999), “Location choice, environmental quality and public policy”, in J. C.J.M. van den Bergh (ed.), Handbook of Environmental and Resources Economics.

Chay, K.Y. and M. Greenstone (2003), “The Impact of Air Pollution on Infant Mortality: Evidence from Geographic Variation in Pollution Shocks Induced by a Recession.” Quarterly Journal of Economics, 118 (3), pp. 1121-67.

Cohen A.J. et al. (2004), "Urban Air Pollution”, Chapter 17 in Comparative Quantification of Health Risks-Global and Regional Burden of Disease Attribution to Selected MajorRisk Factors. The World Health Organization, available at: http://www.who.int/publications/cra/chapters/volume2/13531434.pdf.

EEA (2012), EEA Report No 4/2012, “Air quality in Europe 2012 report” http://www.eea.europa.eu/publications/air-quality-in-europe-2012.

European Union (2008), Directive 2008/50/EC of the European Parliament and of the Council of 21 May 2008 on ambient air quality and cleaner air for Europe (OJ L 152, 11.6.2008, p. 1-44) http://eurlex.europa.eu/LexUriServ/LexUriServ.do?uri=OJ:L:2008:152:0001:0044:EN:PDF.

Environmental Performance Index (2014), “The Global Metrics for the Environment”. http://epi.yale.edu/.

Ferreira, S. et al. (2013), "Life satisfaction and air quality in Europe”, Ecological Economics, Bol. 88®), pp. 1-10.

Gaigne, C., S. Riou and J-F.Thisse, (2012) “Are Compact Cities Environmentally Friendly?”, Ecore Discussion Paper.

Gottdiener M., and L. Budd (2005), Key Concepts in Urban Studies, London, Sage.

Hardoy J., D. Mitlin and D. Satterthwaite (2001), Environmental Problems in an Urbanizing World: Finding Solutions for Cities in Africa, Asia and Latin America, London, Earthscan. 
Kamal-Chaoui, L. and A. Robert (2009), “Competitive Cities and Climate Change”, OECD Regional Development Working Papers, No. 2009/02, OECD Publishing, Paris, http://dx.doi.org/10.1787/218830433146.

Manins P.C. et al. (1998), The impact of urban development on air quality and energy use, in: Proceedings of the 14th International Clean Air and Environment Conference, Melbourne, Mitcham, VIC. Clean Air Society of Australia and New Zealand, pp. 331-336.

Martins, H., A. Miranda and C. Borrego (2012), “Urban Structure and Air Quality”, in: B. Haryanto (ed.), Air Pollution - A Comprehensive Perspective.

OECD (2014a), How's Life in Your Region?: Measuring Regional and Local Well-being for Policy Making, OECD Publishing, Paris, http://dx.doi.org/10.1787/9789264217416-en.

OECD (2013), Regions at a Glance 2013, OECD Publishing, Paris, http://dx.doi.org/ 10.1787/reg_glance2013-en.

OECD (2012a), Redefining “Urban”: A New Way to Measure Metropolitan Areas, OECD Publishing, Paris, http://dx.doi.org/ 10.1787/9789264174108-en.

OECD (2012b), Compact City Policies: A Comparative Assessment, OECD Green Growth Studies, OECD Publishing, Paris, http://dx.doi.org/10.1787/9789264167865-en.

OECD (2014b), The cost of air pollution: Health impacts of road transport. OECD publishing, Paris

Piacentini, M. and K. Rosina (2012), "Measuring the environmental performance of metropolitan areas with geographic information sources”, OECD Regional Development Working Papers, 2012/05, OECD Publishing, Paris, http://dx.doi.org/10.1787/5k9b9ltv87jf-en.

Satterthwaite D. (1999), “The Key Issues and the Works Included”, in D. Satterthwaite (ed.), The Earthscan Reader in Sustainable Cities, London, Earthscan, pp. 3-21.

Silva, J. and Z. Brown (2013), "More than the Sum of their Parts: Valuing Environmental Quality by Combining Life Satisfaction Surveys and GIS Data”, OECD Statistics Working Papers, 2013/01, OECD Publishing, Paris, http://dx.doi.org/10.1787/5k4840hfpwkb-en.

van Donkelaar, A. et al.(2014), "Use of Satellite Observations for Long-Term Exposure Assessment of Global Concentrations of Fine Particulate Matter”, Environmental Health Perspectives, in press.

Wesselink, L.F., E. Buijsman and J.A. Annema (2006), “The impact of Euro 5: facts and figures”. Netherlands Environmental Assessment Agency, MNP report 500043002.

White, M.P. et al. (2013), "Would you be happier living in a greener urban area? A fixed-effects analysis or paner data”, Psychological Science, Vol. 24, No. 6, pp. 920-928.

WHO (2014), “Ambient (outdoor) air pollution database”. http://www.who.int/phe/health_topics/outdoorair/databases/cities/en/.

WHO (2013), Health Effects of Particulate Matter. Policy implications for countries in eastern Europe, Caucasus and central Asia. http://www.euro.who.int/_data/assets/pdf_file/0006/189051/Healtheffects-of-particulate-matter-final-Eng.pdf. 
WHO (2006), Air quality guidelines.

http://whqlibdoc.who.int/hq/2006/WHO_SDE_PHE_OEH_06.02_eng.pdf.

WHO/ Europe (n.d.), Environment and Health Information System (ENHIS)

http://www.euro.who.int/en/data-and-evidence/environment-and-health-information-system-enhis. 


\section{ANNEX A}

Figure 11. Average exposure to PM2.5: Asia and Oceania, 2011

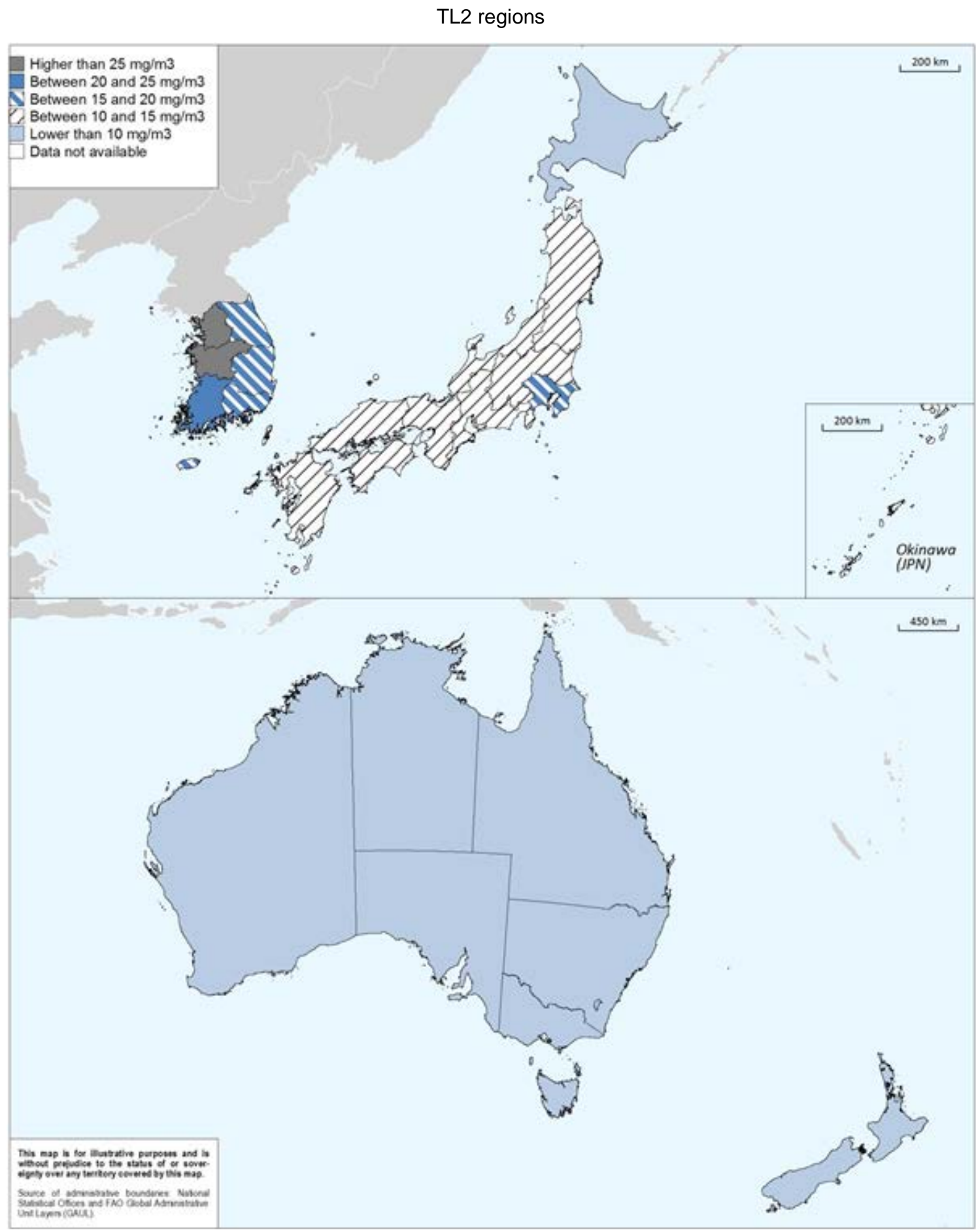

Note: Data refer to three-year average measures (2010-2012).

Source: OECD calculations based on van Donkelaar et al. (2014) 
Figure 12. Average exposure to PM2.5: Europe, 2011

TL2 regions

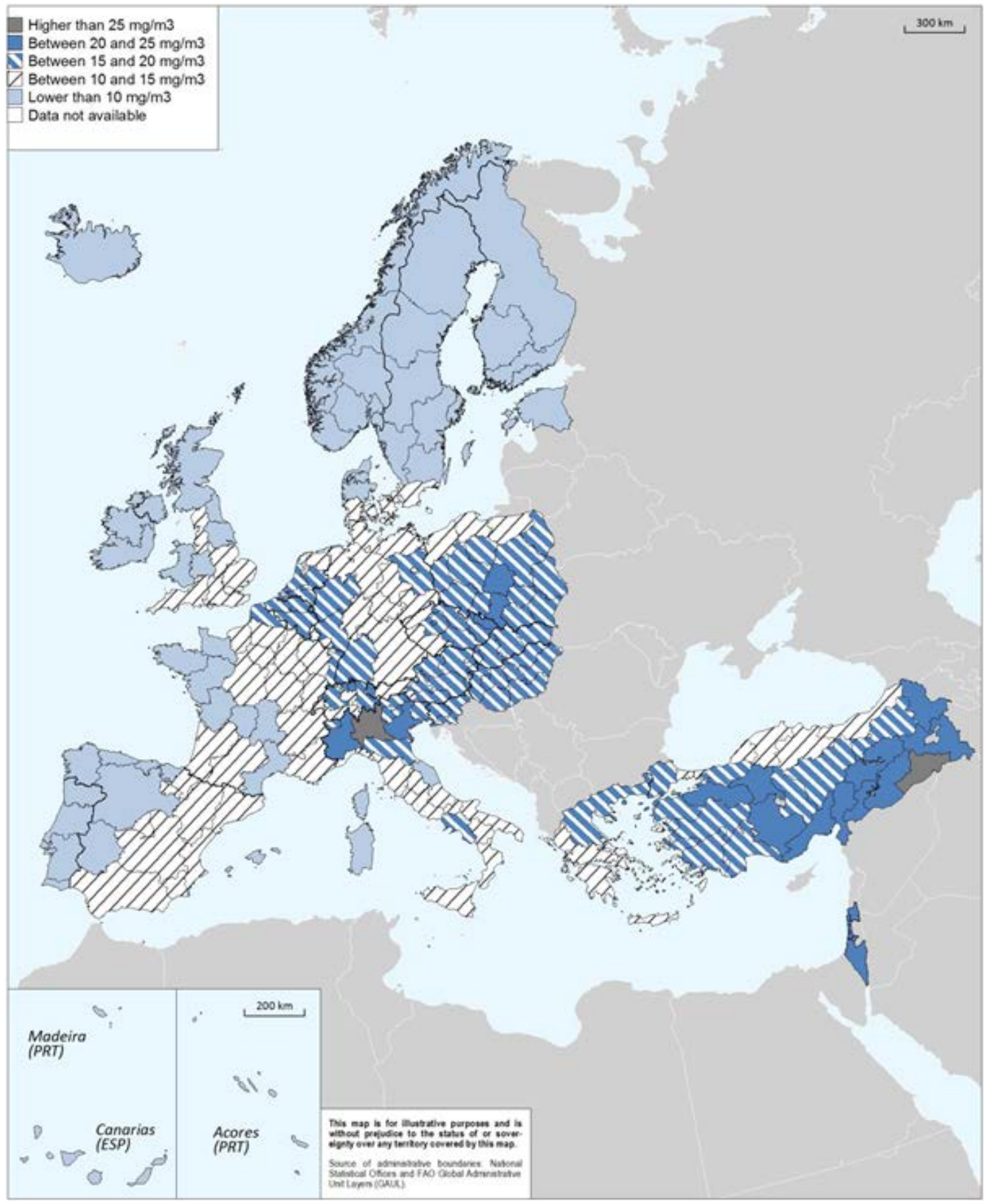

Note: Data refer to three-year average measures (2010-2012).

Source: OECD calculations based on van Donkelaar et al. (2014). 
Figure 13. Average exposure to PM2.5: Americas, 2011

TL2 regions

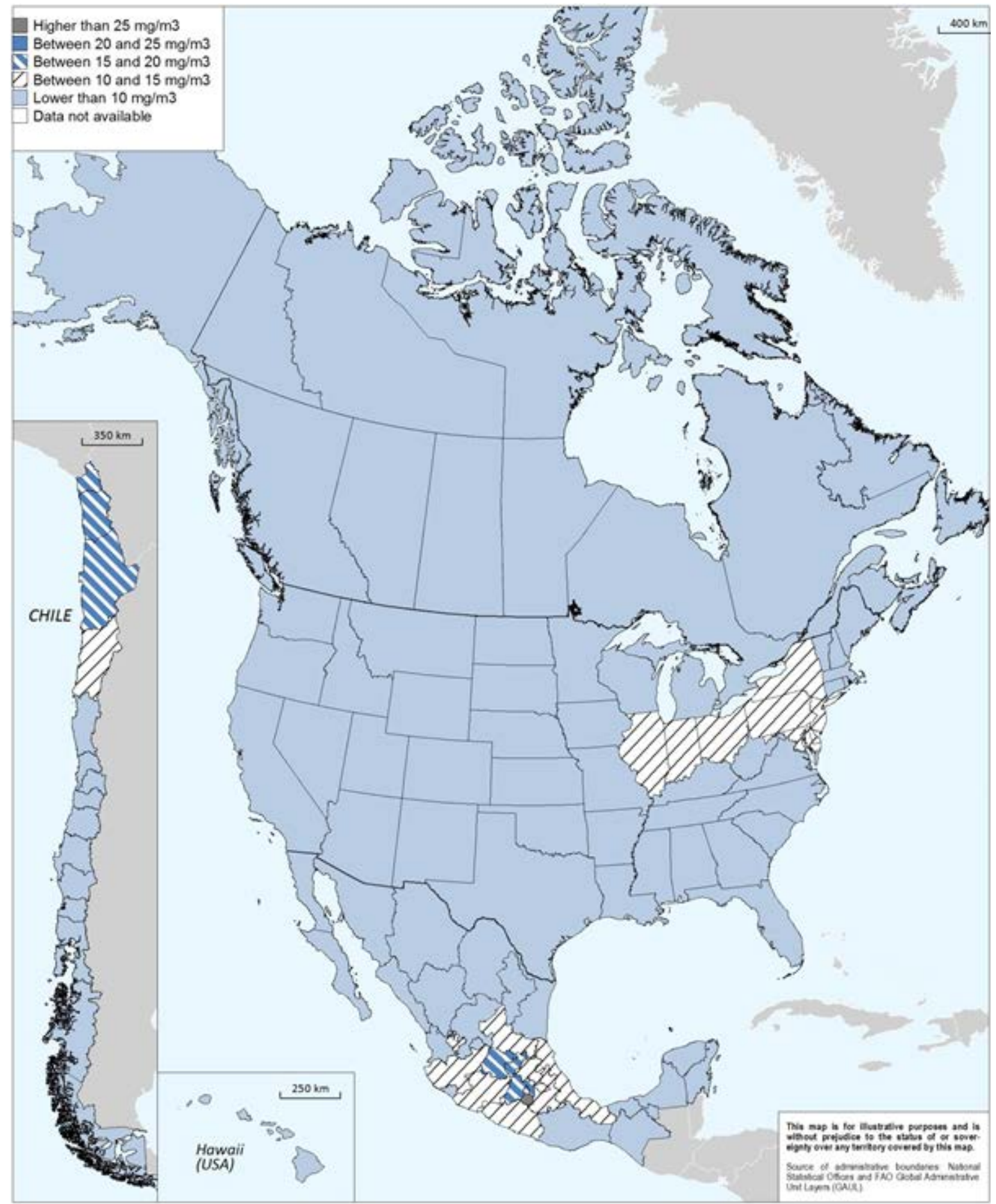

Note: Data refer to three-year average measures (2010-2012).

Source: OECD calculations based on van Donkelaar et al. (2014). 
Figure 14. Average exposure to PM2.5: Emerging economies, 2011

TL2 regions

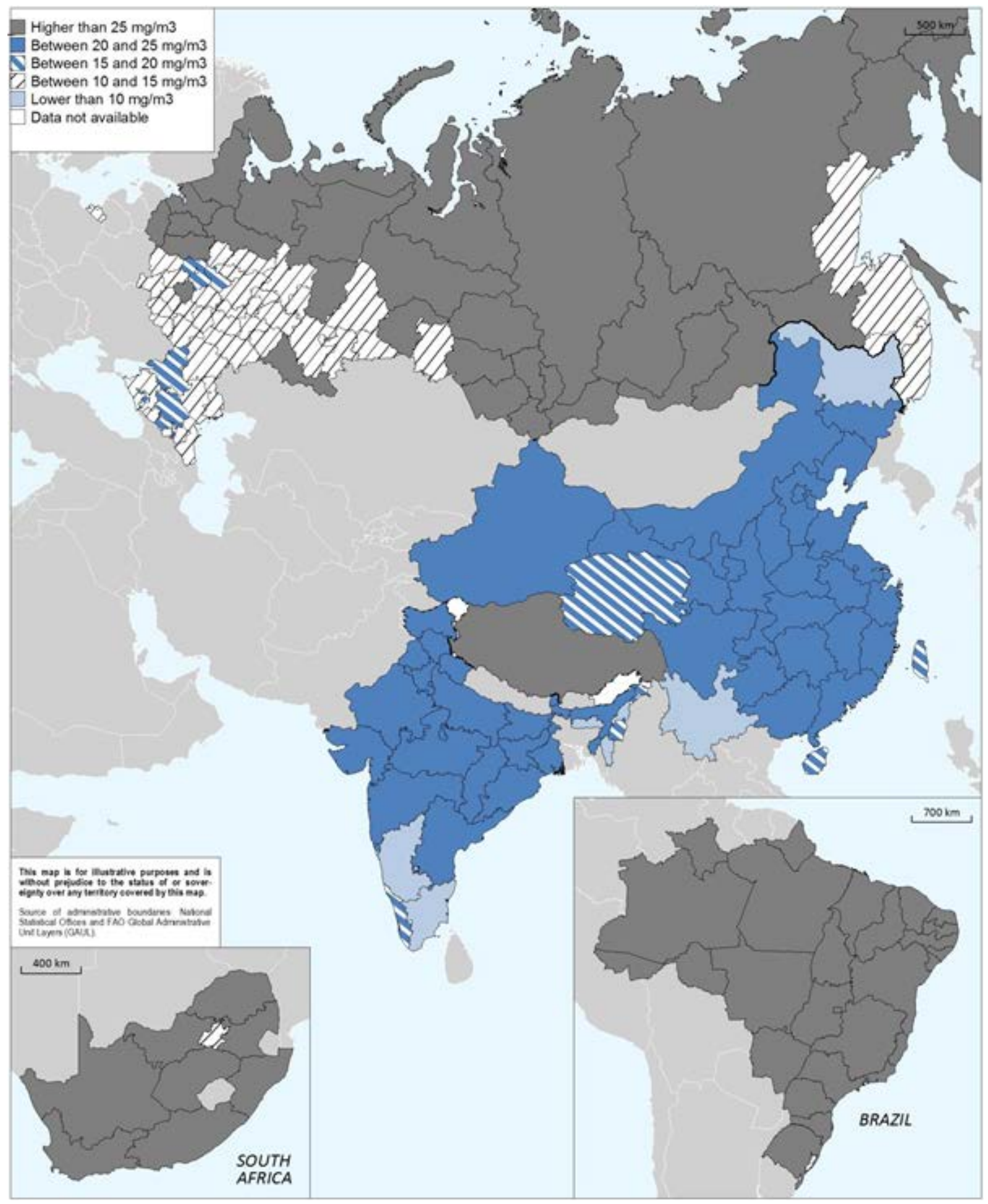

Note: Data refer to three-year average measures (2010-2012).

Source: OECD calculations based on van Donkelaar et al. (2014). 